\title{
Case-Based Learning on Web in Higher Education: A Review of Empirical Research
}

\author{
Danucha Saleewong ${ }^{1}$, Praweenya Suwannatthachote ${ }^{1}$, Supattra Kuhakran ${ }^{2}$ \\ ${ }^{1}$ Faculty of Education, Chulalongkorn University, Bangkok, Thailand \\ ${ }^{2}$ Office of Education Technology, Sukhothai Thammathirat Open University, Bangkok, Thailand \\ Email: danucha_s@hotmail.com, praweenya@gmail.com
}

Received 2012

\begin{abstract}
Case-based learning (CBL) on web makes its challenging students interested and engaged in learning and to develop the skills. Because of the nature of teaching and learning on the web is teaching with the flexibility and comfort without restrictions of time and space with the use of multimedia formats, such as text, audio, video and communication synchronization and asynchronization, students can choose for a presentation. This review summarizes results of this existing research on CBL on web in higher education. Limitations of existing empirical studies are discussed and some directions for future research related to the use of CBL on web in higher education are suggested.
\end{abstract}

Keywords: Case-Based Learning; CBL; Web; E-learning; Digital Learning; Online Learning; Higher Education

\section{Introduction}

When new instructional innovations are introduced to students, they are implicitly or explicitly requested to adjust themselves to the new ways of teaching and learning by their instructors, who believe that new innovations may result in better learning outcomes than the previous approaches (Choi et al., 2009).

Case based learning instruction is one of the constructivist oriented teaching approach (Sudzina, 1997) since it promotes students' active participation so they could form their own learning. Cases are stories with a message which students analyze and consider the solutions of these stories. The teacher and the students are working together while students have controlled analyzing cases. There are many research studies that related to the cases, used in teaching on the web, allow the students to study better (Dabbagh, 2002). In addition, case-based learning helps transfer knowledge and expectations of the students from their learning. The high level knowledge transfer will be more effective with case-based learning and problem solving on the web (Sutyak et al., 1998 and Siegel et al., 2000). This is consistent with the findings of Choi and Lee (2009) who studied the design and development of a case study to enhance learning and problemsolving abilities of students and the study found that the CBLCMPS enhance students' problem solving. It also can be used in real life as well.

Such claims and suggestions, however, have often not been based on empirical studies. This paper reviews the empirical research on Case-based learning on web in higher education to address the question "What does the empirical research indicate about CBL on web" Following a brief description of CBL on web, and common features, we describe our data sources, method of analyses and result findings. In the discussion we focus on directions for future research related to the use of CBL on web in higher education.

\section{Background}

\section{Case-Based Learning on Web}

Case-Based Learning is often defined as a teaching method which requires students to actively participate in real or hypothetical problem situations, reflecting the kinds of experiences naturally encountered in the discipline under study (Ertmer \& Russell, 1995). Case-based learning bridges the gap between theory and practice (Christensen, 1987; Ertmer \& Russell, 1995; Flynn \& Klein, 2001; Shyu, 2000; Williams, 1992). This instructional method is suited for teaching the essential skills of analysis, decision making, critical thinking and problem solving in their professions (Merseth, 1991).

Case-based learning has been extensively used in several areas of professional education such as law, medicine, clinical health, and business as an alternative to the traditional lecture as an instructional method (Artan, 2007; Garvey, O'Sullivan \& Blake, 2000; Marcus, Taylor, \& Ellis, 2004; Williams, 2004).

The key to case-based learning is to create cases for educational purposes and to facilitate activities associated with cases. Cases are like stories for reading and exploring interactively. Cases direct students toward contexts to discuss and debate issues dynamically. Williams (2004) summarizes the benefits of case used for teaching and learning, stating that it allows learners to apply theoretical knowledge to real school contexts, reason critically about complex situations and recommend courses of actions, develop self-knowledge and recognize own assumptions, clarify personal beliefs about teaching, compare and evaluate their own and others' perspectives, and develop the practice of reflection.

While case-based learning challenges students by providing authentic experiences of situations (Williams, 2004), case studies itself will not guarantee the efficacy of online learning processes since some effective pedagogical approaches that instructtors use in their traditional classes may not be applicable for online environments. When case-based learning is implemented online, instructors should be aware that pedagogical activities can be either limited or fostered by conditions associated with technology tools employed. Technology can offer cognitive 
support for students' thinking by reducing working memory limitations, and help them to represent evolving ideas, concepts, and solutions. At the same time, technology can burden students since they have to manage tasks and tool functions simultaneously in the learning processes. (Lee, 2009)

\section{Method}

\section{Sources of Data}

The search for peer-reviewed empirically based articles was conducted in four stages. In the first stage, searches were made in electronic databases using descriptors including case-based learning, CBL. In the second stage, further searches on some of the articles not related with web, e-learning, digital learning, and online learning or technology were carried out. In the third stage, did further searches on some of the articles not related with higher education. And in the last stage, selected the articles published from 2009/01/01-2011/12/31. The electronic databases used for the literature search included Springer, ERIC, and Academic search Premier.

The searches yielded a total of 221 articles. Out of these, 11 were identified for review and 8 of those 11 papers were based on various forms of self-report data (e.g. surveys, interview) or observations, and discussion forum transcripts. The questionnaire survey was the most commonly used as data collection tool. Three papers were based on an experimental design.

\section{Method}

The current review follows the guidelines set by Creswell (1994), which stated that the goal of a review is to summarize the accumulated state of knowledge concerning the topic of interest and to highlight important issues that research has left unresolved. This is accomplished by summarizing the pre- dominant research areas or topics, discussing the weaknesses or limitations of current research, and highlighting several directions for future research related to the use of case-based learning in education.

The basic unit of analysis was each individual empirical article. Using the constant-comparative method espoused by Lincoln and Guba (1985), the coding scheme was not predetermined prior to our analysis but emerged inductively from the data. Specifically, the constant-comparative method involves the following steps: examining each individual article, forming various categories, comparing categories, and achieving category saturation. For example, we began by selecting the first article, reading it, and noting its content to form a tentative research topic category.

\section{Findings}

The categories identified seemed to cluster into two groups: Case-based learning (CBL), we using profile and effects of Case-based learning (CBL) on web. Within each of these, there were two categories, as shown in Table 1.

\section{Case-Based Learning on Web Usage Profile}

Disciplines of study in which CBL on web were used. On the whole, past research on CBL on web had been carried out in four different disciplines: business (e.g., commerce and management), science (e.g., biochemistry), medical (e.g., doctoral), and education (e.g., teacher education). Overall, our analysis of previous research suggested that CBL on web had been most frequently used in the medical discipline (45\%). This was followed by education (28\%), business (18\%), and science (9\%).

How students or instructors use CBL on web. The review found that Case-based learning on web has been applied to a variety of teaching and learning. It addresses the issues of integration of diversified technological tools for pedagogical facilitation of case-based activities and developing multimedia cases in order to enhance student involvement and engagement in understanding contexts embedded in cases toward solutions from multifaceted aspects, as shown in Table 2.

Table 1.

List of major CBL on web topics.

\begin{tabular}{|c|c|}
\hline Topic & Subtopics \\
\hline $\begin{array}{l}\text { Case-based learning } \\
\text { usage profile }\end{array}$ & $\begin{array}{l}\text { Disciplines of study in which case-based } \\
\text { learning were used } \\
\text { How students or instructors use case-based } \\
\text { learning }\end{array}$ \\
\hline $\begin{array}{l}\text { Effects of Case-based } \\
\text { learning }\end{array}$ & $\begin{array}{l}\text { Effects of Case-based learning on } \\
\text { performance outcome } \\
\text { Effects of Case-based learning on affective } \\
\text { outcome }\end{array}$ \\
\hline
\end{tabular}

Table 2.

The review context of CBL on web.

\begin{tabular}{|c|c|}
\hline Study & Context of CBL on web \\
\hline Weil et al. (2011) & $\begin{array}{l}\text { The case-based learning was introduced into } \\
\text { Acct } 210 \text { in an asynchronous discussion mode } \\
\text { using the Moodle open source learning software } \\
\text { platform. } \\
\text { Students used of case-based learning for online } \\
\text { discussion forum }\end{array}$ \\
\hline Hartfield (2010) & $\begin{array}{l}\text { The constructivist teaching strategy aimed to } \\
\text { integrate the teaching and learning activities to } \\
\text { the assessment items, and a set of case-based } \\
\text { learning (CBL) function as the central teaching } \\
\text { and learning activity that facilitates alignment. } \\
\text { Case-based learning used primary biochemistry } \\
\text { research articles as the source of the problems } \\
\text { and integrate (and further develop) the students' } \\
\text { learning with the conceptual theory material } \\
\text { covered within the framework of the lectures. } \\
\text { Students are supported in their acquisition of } \\
\text { competencies and skills in reading, assimilation } \\
\text { and interpretation of primary research articles, as } \\
\text { well as team working and communication skills. }\end{array}$ \\
\hline Bennett (2010) & $\begin{array}{l}\text { Investigated learners' understanding of } \\
\text { multimedia instructional and development } \\
\text { derived from the analysis of two richly detailed } \\
\text { cases, and how this understanding then } \\
\text { supported learners in their own design projects. } \\
\text { Student work from case analysis, group project } \\
\text { and reflective tasks was the key data source, } \\
\text { complemented by interviews with students and } \\
\text { their instructor, observations of class meetings, } \\
\text { and the collection of online discussion list } \\
\text { records and electronic resource files. }\end{array}$ \\
\hline
\end{tabular}




\begin{tabular}{ll}
\hline \multicolumn{1}{c}{ Study } & \multicolumn{1}{c}{ Context of CBL on web } \\
\hline Kim et al. (2011) & $\begin{array}{l}\text { Student used online case-based learning (CBL) } \\
\text { module in the e-learning environment. }\end{array}$ \\
Williams (2009) & $\begin{array}{l}\text { The case-based learning in online environment } \\
\text { used in the clinical curriculum of the Bachelor of } \\
\text { Emergency Health (BEH) degree. Cases were } \\
\text { presented in “web page” format to each e-tutorial } \\
\text { group in Blackboard. }\end{array}$ \\
$\begin{array}{l}\text { Students were given between 8-10 cases and } \\
\text { additional learning resources per semester. }\end{array}$ \\
$\begin{array}{l}\text { Students had online access to cases and } \\
\text { discussions for revision purposes. }\end{array}$ \\
$\begin{array}{l}\text { Students used the online CBL-CMPS } \\
\text { environment. The students were asked to } \\
\text { (2009) } \\
\text { complete Stages 1, 2, and 3 of the CBL-CMPS } \\
\text { online and to submit their responses to the } \\
\text { questions (problem identification and solution } \\
\text { generation) posed at the end of each stage as a } \\
\text { homework assignment and they checked out } \\
\text { Stages 4 and/or 5 (one case did not have Stage 5) } \\
\text { for another homework assignment in the same } \\
\text { way that they did for the previous stages. }\end{array}$ \\
$\begin{array}{l}\text { Students used case-based e-learning environment } \\
\text { in anesthesiology course. }\end{array}$ \\
\hline Choi et al. (2009)
\end{tabular}

\section{Effects of Case-Based Learning on Web}

Effect of case-based learning on web on performance outcome, researchers were also interested in examine whether CBL on web could enhance thinking skill or participants' learning, as shown in Table 3.

Effect of case-based learning on web on affective outcome, researchers were also interested in affective outcome such as attitudes and satisfaction of using CBL on web. Most students agreed that the CBL on web was easy to use and had exciting experience to explore technologies and that CBL on web was fun and interesting, as shown in Table 4.

\section{Conclusion}

Our review found several limitations concerning previous empirical studies on CBL on web in higher education. We found that previous research studies related to CBL on web usage were limited mainly to discussion or technology-related disciplines such as medical, education and business. The duration of the research on CBL on web usage is another limitation identified. Most research studies were largely conducted over a period of one semester.

In some study that used experimental design, to compare between the use case-based learning and case-based learning with technology. For example, the study of Choi and Lee (2009), these results indicated that two of the seven sub-skills gained during the CBL-CMPS experience were transferred to a new case problem while three of the other sub-skills showed positive potential for the transfer effects to some degree. To illustrate how students' answers were improved from the pretest to the posttest. The results showed that the CBL-CMPS and its stages facilitated the college students in a) considering multiple perspectives, b) critically reviewing situations and solutions in
Table 3.

Review of CBL on web performance outcome.

\begin{tabular}{ll}
\hline \multicolumn{1}{c}{ Study } & \multicolumn{1}{c}{ Performance outcome } \\
\hline $\begin{array}{l}\text { Choi and Lee } \\
\text { (2009) }\end{array}$ & $\begin{array}{l}\text { The individual components of the CBL-CMPS promoted } \\
\text { ill-structured problem solving abilities respectively, and } \\
\text { that the CBL-CMPS as a whole learning environment was } \\
\text { effective to a degree for the transfer of learning in } \\
\text { ill-structured problem solving. The potential, challenge, } \\
\text { and implications of the CBL-CMPS are discussed }\end{array}$ \\
Cirai et al. & $\begin{array}{l}\text { Students responded that, apart from helping them acquire } \\
\text { (2010) } \\
\text { substantive knowledge in microbiology, CBL sessions } \\
\text { enhanced their analytic, collaborative, and communication } \\
\text { skills. }\end{array}$ \\
$\begin{array}{l}\text { Hartfield } \\
\text { (2010) }\end{array}$ & $\begin{array}{l}\text { Students perceive that this approach enables the } \\
\text { development of problem-solving skills and confirms that } \\
\text { students identify a high degree of alignment between } \\
\text { teaching and learning activities and assessment. And a } \\
\text { case-based learning paradigm can facilitate constructive } \\
\text { alignment of teaching and learning activities with } \\
\text { assessment, and that this approach supports and bolsters } \\
\text { students' satisfaction and leads to improved academic } \\
\text { performance of students. }\end{array}$ \\
$\begin{array}{l}\text { Students perceive numerous benefits associated with } \\
\text { case-based online discussions, including being exposed to } \\
\text { other students' opinions, improving their ability to } \\
\text { critically review case information, motivation to consult } \\
\text { additional non-course related material and the convenience } \\
\text { of the technology utilized. }\end{array}$ \\
$\begin{array}{l}\text { Wennett } \\
\text { (2010) }\end{array}$ & $\begin{array}{l}\text { It addresses the issues of integration of diversified } \\
\text { technological tools for pedagogical facilitation of } \\
\text { case-based activities and developing multimedia cases in } \\
\text { order to enhance students' involvement and engagement in } \\
\text { understanding contexts embedded in cases toward solutions } \\
\text { from multifaceted aspects. }\end{array}$ \\
$\begin{array}{l}\text { The result that the case analysis task raised learners' } \\
\text { awareness of design approaches and project management } \\
\text { strategies, and that discussion and reflection play critical } \\
\text { roles in developing students' understanding. The study also } \\
\text { highlighted some limitations of the case approach, } \\
\text { suggesting the need for strategies that support learners' } \\
\text { thinking and reasoning. }\end{array}$ \\
\hline
\end{tabular}

Table 4.

Review of CBL on web affective outcome.

\begin{tabular}{ll}
\hline \multicolumn{1}{c}{ Study } & \multicolumn{1}{c}{ Affective outcome } \\
\hline $\begin{array}{l}\text { Kim et al. } \\
\text { (2011) }\end{array}$ & $\begin{array}{l}\text { CBL module showed higher average scores than the } \\
\text { comparison group across all scores: Easy to use Easy } \\
\text { to learn Usefulness and Satisfaction. }\end{array}$ \\
$\begin{array}{l}\text { Hartfield } \\
(2010)\end{array}$ & $\begin{array}{l}\text { Case-based learning paradigm supports and bolsters } \\
\text { student satisfaction and leads to improved student } \\
\text { academic performance. }\end{array}$ \\
\hline
\end{tabular}

social and historical contexts, c) developing coherent arguments, and d) applying theories to their arguments to a certain degree while solving ill-structured problems. In the study of Kim et al. (2011) the experimental design by treatment groups using tutorial with case-based learning (CBL) module and comparison groups using tutorial only. The results found that a significant increase in the level of domain knowledge in both a tutorialonly group and a tutorial with CBL module group. The tutorial with CBL group scored significantly higher on learners' perceptions of the e-learning environment in terms of use, satisfac- 
tion, and usefulness.

Our review of the effects of CBL on web on the affective domain leads us to a better understanding of the personal or environment-related factors that could impede the use of CBL on web by students in higher education. The review found that the use of CBL on web is useful and easy to use.

Technology applied to education was more important. Since technology is not the only medium of teaching anymore but the process of using technology to improve student learning and further education in the 21st century is what makes teaching more effective. Case-Based Learning on Web is the challenge to help students develop skills and interests. Due to the nature of the course, it is taught on a flexible and convenient. There are no restrictions in terms of time and place. Several multimedia formats can be used such as voice, video and visual communication through the synchronous and asynchronous communication. The students can choose the presentation format and be controlled according to the instruction which will enhance teaching and learning more.

The use of CBL on web or CBL with technology is an emerging trend. We hope that this review will be useful to researchers and educators as they continue to study and build a knowledge base concerning the use of CBL on web in higher education.

Future research need to discuss and imply assessment methods to measure students' outcome related to deep learning and advance skill in the CBL on web suitable for learning in the 21st century.

\section{Acknowledgements}

I gratefully acknowledge the Office of the Higher Education Commission for supporting the research funds.

\section{REFERENCES}

Artan, A. E. (2007). Case-based discussions in an educational psychology course: Problem solving processes and interactions. Unpublished doctoral dissertation, University of Pittsburgh, USA.

Bennett, S. (2010). Investigating strategies for using related cases to support design problem solving. Education Technology Research and Development, (2010)58, 459-480.

Choi, I and Lee, K. (2009). Designing and Implementing a Case-based Learning Environment for Enhancing Illstructured Problem Solving: Classroom Management Problems for Prospective Teachers. Education Technology Research and Development, 57(2009): 99-129.

Choi, I., Lee, S.J., \& Kang, J. (2009). Implementing a case-based e-learning environment in a lecture-oriented anaesthesiology class: Do learning styles matter in complex problem solving over time?. British Journal of Educational Technology, 40(5), 933-947.

Christensen, C. R. (1987). Teaching and the case method. Boston: Harvard Business School

Ciraj, A.M., Vinod, P., \& Ramnarayan, K. (2010). Enhancing active learning in microbiology through case based learning: Experiences from an Indian medical school. Indian Journal of Pathology and Microbiology, 53(4), 729-734.

Creswell, J. (1994). Research design qualitative and quantitative approaches. Thousand Oaks: Sage Publications.

Dabbagh, N. (2002). Assessing Complex Problem-Solving Skill and Knowledge Assembly Using Web-Based Hypermedia Design. Journal of Educational Multimedia and Hypermedia. 11(2002), 291-322.

Ertmer, P.A., \& Russell, J.D. (1995). Using case studies to enhance instructional design. Educational Technology,35(4), 23-31.

Flynn, A. E. and Klein, J. D. (2001). The Influence of Discussion
Group in a Case-Based Learning Environment. Educational Technology Research and Development. 49(3).

Garvey, M. T., O’Sullivan, M., \& Blake, M. (2000). Multidisciplinary case-based learning for undergraduate students, European Journal of Dental Education, 4(4), 165-168.

Hartfield, P.J. (2010). Reinforcing constructivist teaching in advanced level biochemistry through the introduction of case-based learning activities. Journal of Learning Design, 3(3), 20-31.

Kim, H.J., Pederson, S., \& Baldwin, M. (2011). Improving user satisfaction via a case-enhanced e-learning environment. Education Training, 54(2/3), 204-218.

Lee, S-H., Lee, J., Liu, X., Bonk, C.J., \& Magjuka, R.J. (2009). A review of case-based learning practices in an online MBA program: A program-level case study. Educational Technology \& Society, 12 (3), 178-190.

Lincoln, Y.S.,\& Guba, E.G. (1985). Naturalistic inquiry. Beverly Hills, CA: Sage Publications.

Marcus, G., Taylor, R., \& Ellis, R. A. (2004). Implications for the design of online case based learning activities based on the student blended learning experience. In R. Atkinson, C. McBeath, D. Jonas-Dwyer, \& R. Phillips (Eds.), Beyond the comfort zone: Proceedings of the 21st ASCILITE Conference (pp. 557-586). Perth, Western Australia.

Merseth,K.K. (1991). The early history of case-based instruction: Insights for teacher education today. Journal of Teacher Education, 42(4), 243-249.

Ramaekers, S., Keulen, H-V., Kremer, W., Pilot, A., \& Beukelen, P-V. (2011). Effective Teaching in Case-based Education: Patterns in Teacher Behavior and Their Impact on the Students' Clinical Problem Solving and Learning. International Journal of Teaching and Learning in Higher Education, 23(3), 303-313.

Shyu, H. C. (2000). Using video-based anchored instruction to enhance learning: Taiwan's experience. British Journal of Educational Technology, 31(1), 57-69.

Siegel, M., Derry, S., Kim, J., Steinkuehler, C., Street, J., Canty, N., Fassnacht, C., Hewson, K., Hmelo, C., and Spiro, R. (2000). Promoting teachers' flexible use of the learning sciences through case-based problem-solving on the WWW: A theoretical design approach. In B. Fishman \& S. O’Connor-Divelbiss (Eds.), Proceedings of the Fourth International Conference of the Learning Sciences. Mahwah, NJ: Erlbaum. 273-279.

Stark, R., Kopp, V., \& Fischer, M.R. (2011). Case-based learning with worked examples in complex domains: Two experimental studies in undergraduate medical education. Learning and Instruction, 21(2011), 22-33.

Sudzina, M. (1997). Case study as a constructivist pedagogy for teaching educational psychology. Educational Psychology Review, 9(2), 199-218.

Sutyak, J. P., Lebeau, R. B., and O’Donnell, A. M. (1998). Unstructured cases in case based learning benefit students with primary care career preferences. The American Journal of Surgery. (June, 1998), 175.

Weil, S., McGuigan, N., Kern, T. (2011). The usage of an online discussion forum for the facilitation of case-based learning in an intermediate accounting course: a New Zealand case. Open Learning, 26(3), 327-251.

Williams, B. (2009). Do undergraduate paramedic students embrace case based learning using a blended teaching approach? A 3-year review. Australasian Journal of Educational Technology, 25(3), 421-439.

Williams,M. (2004). Exploring the effects of a multimedia case-based learning environment in pre-service science teacher education in Jamaica. Unpublished doctoral dissertation, University of Twente, The Netherlands.

Williams,S.M. (1992). Putting case-based instruction into context: Examples from legal and medical education. The Journal of Learning Sciences, 2(4), 367-427. 